graduate training in Russian literature with a year at the Charles University and then returned to Berkeley, where he taught as a lecturer while working for his doctorate. In 1942 he defended his dissertation on "The Young Andrei Bely and the Symbolist Movement in Russia, 1901-1909" and was at once invited to join Noyes, Alexander Kaun, and George Patrick as their junior colleague on the regular academic staff. Within a scant two years, he was obliged to assume the chairmanship of the Department, beginning a long period of self-sacrificing administrative work made all the more onerous by the new needs for intensive Russian language programs and by the rapid growth of Slavic area studies after the war.

Despite such heavy demands on his time, the young Professor Maslenikov continued to grow as scholar and teacher, and to the end he remained actively and productively engaged in both literary and linguistic scholarship, as attested by a steady flow of articles and reviews, as well as by many still unpublished lectures that he read at meetings of learned societies. The results of his doctoral research were refined and presented to the general public in 1952, in the book entitled The Frenzied Poets, which has been deservedly recognized as a classic in its field. Among his later publications special mention should be made of his papers devoted to the influence of Ruskin on Russian literature, his metrical and thematic analyses of the poetry of Zinaida Gippius, and his studies on Dostoevsky.

Having come to this country from Vladivostok at an early age, he enjoyed the advantage of combining a native knowledge of Russian with an impeccable command of English. Nowhere is that advantage better displayed than in the fruits of his favorite avocation-the translation of Russian poetry. Thanks to the devoted efforts of his widow, Emily Maslenikov, the selection that he himself had prepared of his verse translations-mainly, but not exclusively, from the Symbolists-has now been published in a bilingual edition under the title Lyrics from the Russian: Symbolists and Others. For his many colleagues and students who had the privilege of hearing his vigorously beautiful public readings, the appearance of this book will constitute the most fitting tribute to his memory-a monument to his overpowering love of poetry and to his uncommon skill in communicating his enthusiasm to others.

Francis J. WhitField

University of California, Berkeley

\title{
SERGEI LEONIDOVICH PESHTICH, 1914-1972
}

S. L. Peshtich was born in Orenburg, the son of a prominent Russian petroleum engineer. Choosing to follow his father's career, he completed the Grodno Petroleum Tekhnikum and worked from 1933 to 1935 on the construction of an oil pipeline. At the same time he completed an evening course at the party higher school (komvuz) and then taught political economy and party history at the Guriev Petroleum Tekhnikum. In 1936 he entered Leningrad University, where he remained, except for World War II, as student and teacher until his death. Already as an undergraduate he displayed that interest in the study of Russian historiography and sources which dominated his academic work for more than three decades. His diploma work, written under the guidance of Professor M. D. Priselkov, earned first prize in university competition in 1940, the year of his graduation. He interrupted formal graduate work to serve in the Baltic Fleet 
throughout the war, yet nevertheless succeeded in defending his candidate's dissertation in September 1944 on the subject "The Russian History of V. N. Tatishchev as a Historical Source." He returned to the university in 1946, became docent in 1949 and professor in 1966. He taught general courses in early modern Russian history and historiography and specialized courses in eighteenth-century intellectual history and historiography. In November 1963 he defended his major work, the doctoral dissertation entitled Russkaia istoriografiia XVIII v. (see Slavic Review, June 1973, p. 377), parts of which appeared as well in learned journals. His scholarly legacy includes unpublished work on N. M. Karamzin and Tatishchev, as well as a monograph, written in the late 1940 s, on Russian naval historiography.

\section{JOAN AFFERICA Smith College}

Statement of Ownership, Management and Circulation required by the Act of August 12, 1970; Section 3685, Title 39, United States Code.

1. Title of publication: Slavic Review.

2. Date of filing: October 1, 1973.

3. Frequency of issue: Quarterly: March, June, September, December.

4. Location of known office of publication: 190 West 19th Ave., The Ohio State University, Columbus, Ohio 43210.

5. Location of the headquarters or general business offices of the publishers: 190 West 19th Ave., The Ohio State University, Columbus, Ohio 43210.

6. Publisher: American Association for the Advancement of Slavic Studies, 190 West 19th Ave., The Ohio State University, Columbus, Ohio 43210. Editor: Donald W. Treadgold, Thomson Hall, University of Washington, Seattle, Washington 98195. Managing Editor: None.

7. Owner: (If owned by a corporation, its name and address must be stated and also immediately thereunder the names and addresses of stockholders owning or holding 1 percent or more of total amount of stock. If not owned by a corporation, the names and addresses of the individual owners must be given. If owned by a partnership or other unincorporated firm, its name and address, as well as that of each individual must be given.) American Association for the Advancement of Slavic Studies, 190 West 19th Ave, The Ohio State University, Columbus, Ohio 43210 .

8. Known bondholders, mortgagees, and other security holders owning or holding 1 percent of more of total amount of bonds, mortgages or other securities: None.

9. For optional completion by publishers mailing at the regular rates (Section 132.121, Postal Service Manual). 39 U. S. C. 3626 provides in pertinent part: "No person who would have been entitled to mail matter under former section 4359 of this title shall mail such matter at the rates provided under this subsection unless be files annually with the Postal Service a written request for permission to mail matter at such rates." In accordance with the provisions of this statute, I hereby request permission to mail the publication named in Item $I$ at the reduced postage rates presently authorized by 39 U. S. C. 3626 . (Signature of executive secretary: GeORGe KaLbooss).

10. For completion by nonprofit organizations authorized to mail at special rates (Section 132.122, Postal Manual): The purpose, function, and nonprofit status of this organization and the exempt status for Federal income tax purposes have not changed during preceding 12 months.

11. Extent and nature of circulation

A. Total no. copies printed (net press run) $\ldots \ldots \ldots 4,300 \quad 4,402$

B. Paid circulation

1. Sales through dealers and carriers, street vendors and counter sales .... None None

2. Mail subscriptions .. $3,900 \quad 3,819$

C. Total paid circulation .. $3,900 \quad 3,819$

D. Free distribution by mail, carrier or other means

1. Samples, complimentary, and other free copies ........

2. Copies distributed not sold $\ldots \ldots \ldots$ None None

E. Total distribution (sum of $G$ and $D) \ldots \ldots \ldots 4,000 \quad 3,944$

F. Office use, left-over, unaccounted, spoiled after printing $\ldots \ldots \ldots \ldots$

G. Total (sum of E \& F -should equal net press run shown in A) 4,300 4,402

I certify that the statements made by me above are correct and complete.

Gronge KaI,Bouss, AAASS Executive Secretary

-Average number of copies for each issue during preceding 12 months.

fActual number of copies of single issue published nearest to filing date. 